\title{
New record of lochroma arborescens (Solanaceae) for India, a potential invasive plant from America with notes on its typification
}

\author{
Santhosh Nampy ${ }^{*}$, Divya K. Venugopal, Dani Francis \& Vishnu Mohan \\ 2Department of Botany, University of Calicut, Malappuram P.O., Kerala- 673 635, India. \\ *Email: santhoshnampy2019@gmail.com
}

\begin{abstract}
Iochroma arborescens (L.)J.M.H.Shaw (Solanaceae), a potential invasive species from America, is authentically recorded for the first time in India. Perusal of relevant literature revealed that the name has yet to be typified. Details of the taxonomy, distribution and invasive nature of this species with notes on its typification are provided here.
\end{abstract}

Keywords: Allelopathy, Idukki district, Iochroma, Kerala, Maharashtra, Typification.

\section{INTRODUCTION}

While documenting the angiosperm diversity of the floristically rich Idukki district in Kerala, the authors collected some interesting specimens of the family Solanaceae. Detailed examination revealed its identity as Iochroma arborescens (L.) J.M.H. Shaw, a species so far not reported from India. The genus Iochroma Benth. includes nearly c. 26 species worldwide (Mabberley, 2017; but IPNI records 98 names under Iochroma), ranging from Mexico to Tropical America. Iochroma arborescens is an invasive weed distributed in American countries such as southern Mexico, central and South America (Shaw, 2018). The occurrence and distribution of this species in India is yet to be resolved, and this species has not been included in the list of invasive plants/ weeds in India. A perusal of relevant literature also revealed that the name is yet to be typified. The present paper discusses the taxonomy, distribution, invasive nature and typification of Iochroma arborescens in India.

Received: 30.8.2018; Revised \& Accepted: 20.05.2019

Published Online: 30.09.2019

\section{Taxonomic treatment}

Iochroma arborescens (L.)J.M.H.Shaw, Plantsman 17(3): 200. 2018. Atropa arborescens L., Cent. Pl. II: 10. 1756. Acnistus arborescens (L.) Schltdl., Linnaea 7: 67. 1832. Neotype (designated here): Plumier, Pl. Amer. fasc. 2. t. 46. f. 1. $1756 . \quad$ Figs. 1 \& 2

Unarmed shrubs or small trees, up to $2 \mathrm{~m}$ tall, glabrous throughout. Stems terete, branched, greyish-white. Leaves simple, alternate; petioles 1-2 cm long, glabrous; lamina elliptic, 18-24 × 6-9 cm, acute to attenuate at base, acute at apex, entire at margins, both surfaces glabrous, pale green. Inflorescence a many flowered fascicle, cauliflorous. Flowers bisexual, actinomorphic, c. $2 \times 1 \mathrm{~cm}$; pedicels c. $1 \mathrm{~cm}$ long. Calyx 5-lobed cupular; lobes c. $3 \times 1 \mathrm{~mm}$, hairy outside, acute at apex, green. Corolla 5-lobed; tube c. $4 \times 1 \mathrm{~mm}$; lobes $c .8 \times 1 \mathrm{~mm}$, nearly elliptic, greenish-white with yellow tinge on inner surface, papillate along margins. Stamens 5, equal, exserted; filaments $c$. 5.1 $\mathrm{mm}$ long, epipetalous, glabrous, cream coloured; anthers oblong, c. $2 \times 2 \mathrm{~mm}$, dithecous, dorsifixed, yellow coloured. Ovary 2-celled, ovoid, c. $2 \times 1$ $\mathrm{mm}$; ovules many; styles slender, c. $7 \times 1 \mathrm{~mm}$; stigma capitate. Berries globose, c. $5 \mathrm{~mm}$ long.

Flowering \& fruiting: April-June.

Distribution: South and central America (Brazil, Peru, Ecuador, Colombia, Venezuela, Costa Rica and Nicaragua), southern Mexico and now in India.

Habitat: Road side (damp areas); as fencing material at elevations around $1200 \mathrm{~m}$.

Specimen examined: INDIA, Kerala, Idukki district, Painavu, 04.04.2018, Divya K. Venugopal \& Santhosh Nampy 158483 (CALI). 

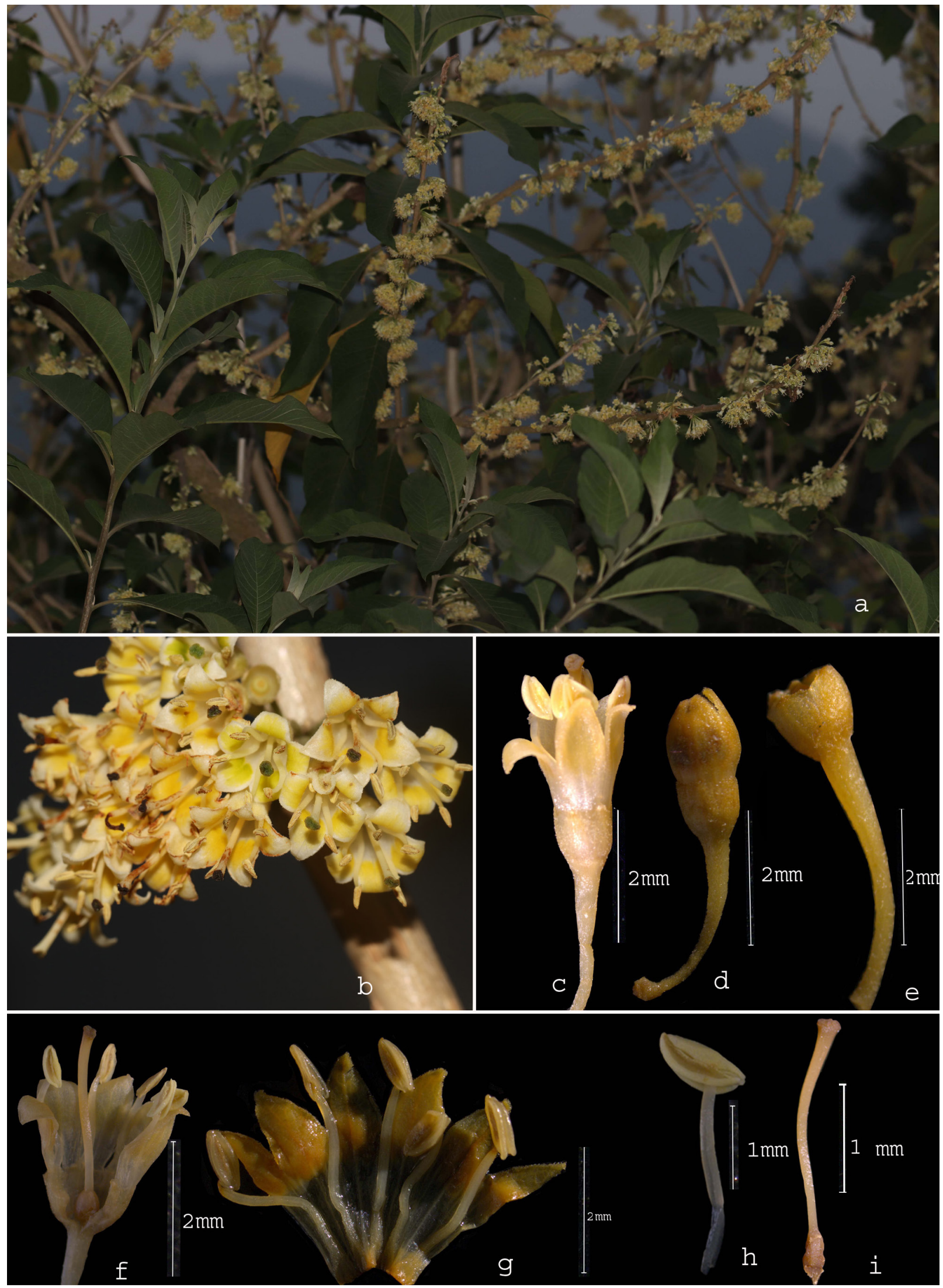

Figure 1. lochroma arborescens (L.)J.M.H.Shaw: a. Habit; b. Flowering twig; c. Flower; d. Bud; e. Sepal; f. Flower opened; g. Corolla opened; h. Stamen; i. Carpel. 


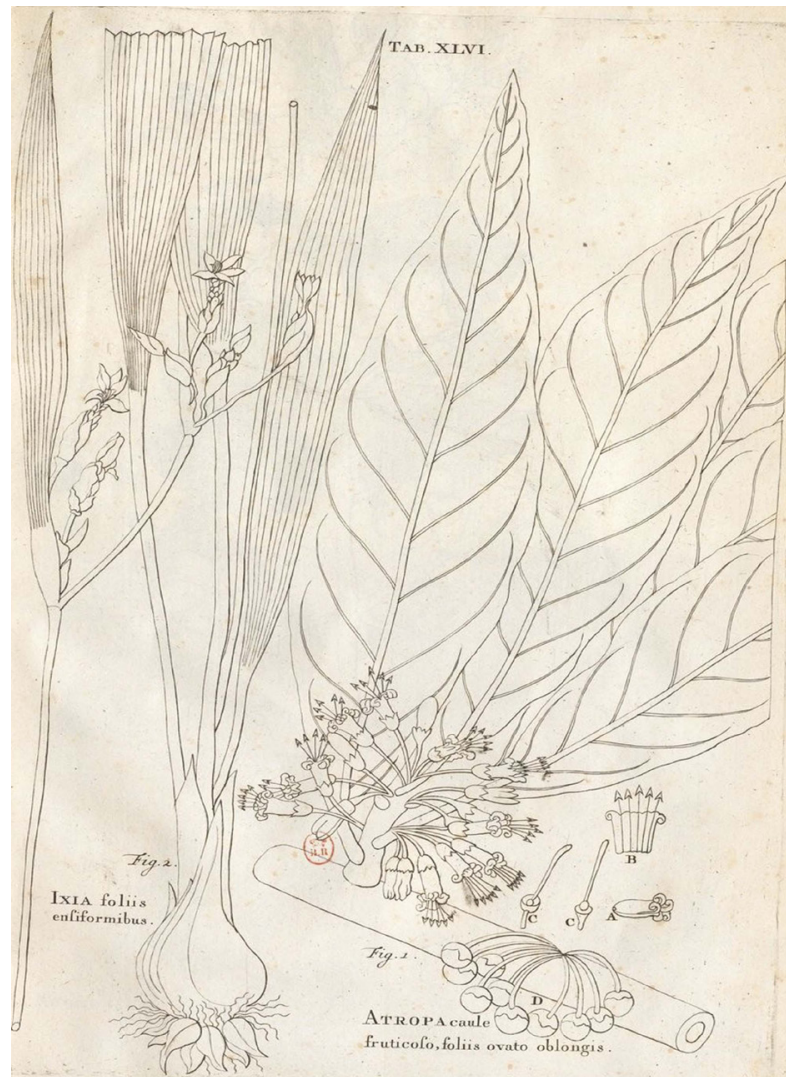

Fig. 2. Neotype of lochroma arborescens (L.) J.M.H. Shaw (Plumier, PI. Amer. fasc. 2. t. 46. f.1. 1756).

Notes: This species is usually found growing well in open sunny locations. It produces large number of cauliflorous flowers and fruits.

\section{Typification}

Iochroma arborescens was originally described as Atropa arborescens by Linnaeus (1756) in Centuria II Plantarum as "Atropa (arborescens) caule frutescens, pedunculis confortis, corollis limbo revolutis, foliis ovato-oblongis. Belladonna frutescens, flore albo, nicotianae foliis. Plum spec.1". The 'Plum spec. 1' refers to the species 1 in Catalogus Plantarum Americanarum, Nova Plantarum Americanarum of Plumier (1703), in which only the phrase-name (nomen specificum legitimum) cited by Linnaeus (1756) appears. Later, in Plumier's Plantarum Americanarum, in which Burman presented details of plants from Islands of Antilles once seen and drawn by Charles Plumier, included "Bella Donna frutescens, flore albo, Nicotianae foliis. Plum. Cat. pl. Amer p. 1. Tourn. Inst. P. 77." along with a description and illustration [fascicle 2, p. 34, t. 46, figure 1]. This set was seen by Linnaeus during his stay in Holland for the description of Atropa arborescens in Centuria II plantarum (Stafleu \& Cowan, 1983). According to Jarvis (2007), the type of this name has not yet been designated as per Linnaean typfication databases. Although Howard (1989) attempted to typify the name in the Flora of Lesser Antilles by referring to Plum. Spec. 1 as type, this is ineffective as he failed to indicate the illustration in Plantarum Americanarum (t.46. f.1). Moreover, Linnaeus also, did not refer to this illustration, and so as noted in the Linnaean typfication database no original material has been traced. Since no original material is present, the illustration t.46. f. 1 can be considered as a neotype (Art 40.3) as per Shenzhen Code (Turland et al., 2018).

\section{Notes on invasive nature}

The species is native to America and is commonly called Wild tobacco, Gallinero, Hollow heart etc. (Chimera, 2012). It is an edible non-crop plant, actively managed in home gardens as an ornamental plant and also for chicken fodder (berries), hedging and as a honey shrub in American countries (Eynden, 2004). It is a rapid growing plant propagated through seeds and stem cuttings and has some medicinal properties (Kupchan et al., 1965, 1969; Barata et al., 1970).

How this plant got introduced in India is still a question unresolved. The name is not included in any of the Floras of India (Roxburgh, 1795; Clarke 1885; Gamble, 1921; e-flora India, 2014). It is also not included in Invasive plants of India (Reddy et al., 2008), Invasive Alien Plant Species of Tamil Nadu (Narasimhan et al. 2009), Handbook on Weed identification (Naidu, 2012) and Weeds and weed management in India (Rao \& Chauhan, 2015). Even though this plant is reported as a cultivated species by Reema Kumari (2004, unpublished), based on a specimen collected from Pune, Maharashtra (D.K. Kulkarni s.n., AHMA), it has not been reported in any of the subsequent floras (Sharma et al., 2000). Hence this is the first report of this species from India.

Chimera (2012) reported that, the plant is allelopathic in nature and has the ability to inhibit the growth of nearby plants and to colonize in a newly introduced area. In India, this species is planted as a fencing material and ornamental plant. 
So there is a chance for this species to become massive in population in near future due to its rapid growth and allelopathic nature.

\section{Acknowledgements}

The authors are grateful to The Head, Department of Botany, University of Calicut for facilities; Dr. K.N. Gandhi (Harvard University), Dr. John McNeill (Royal Botanic Garden, Edinburgh) and Dr. Subir Bandyopadhyay (CNH, Kolkata) for nomenclatural discussions; Principal Chief Conservator of Forests (Kerala) and Range Officers for permission to undertake field trips in Idukki district; Dr. Sandra Knapp (BM), Ms. Lesley Scott (E), Mr. Jacek Wajer (BM) for providing relevant literature and Kerala State Council for Science, Technology and Environment, Thiruvananthapuram for financial assistance (126/2016/ KSCSTE dated 26.05.2016).

\section{Literature Cited}

BARATA L., MORS W.B., KIRSON I. \& D. LAVIE 1970. A new withanolide from Acnistus arborescens (L.) Schtdl. (Solanaceae) from the Guanabara, Brazil. Anais da Academia Brasileira de ciencias 42: 401-407.

BURMAN J. 1756. Plantarum Americanarum fasciculus primus [decimus]: continens Plantas, quas olim Carolus Plumierius, botanicorum Princeps detexit, eruitque, atque in insulis Antillis ipse depinxit. Fascicle 2. Amstelaedami Lugd Batav: Sumtibus Auctoris, Prostant in Horto Medico, atque Apud Viduam \& Filium S. schouten; Apud G. Potuliet \& T. Haak. p. 34.

CHIMERA C. 2012. WRA species report - Hawaiian ecosystems at risk. Available at http:/www.hear.org/ (accessed on 26.07.2018).

CLARKE C.B. 1885. Loganiaceae. In: HOOKER J.D. (Ed.), The Flora of British India. Volume 4. L. Reeve \& Co., London. pp. 228-246.

EFLORA OF INDIA 2014. Botanical Survey of India. Available at http://efloraindia.nic.in/. (accessed on 26.07.2018).

EYNDEN DEN V.V. 2004. Use and management of edible non-crop plants in southern Ecuador. Ghent University, Belgium. p. 114.

GAMBLE J.S. 1921. The Flora of Presidency of Madras. Volume 2. Adlard \& Son Ltd., London. pp. 931-942.

HOWARD R.A. 1989. The Flora of the Lesser Antilles: Dicotyledonae. Volume 6. Arnold Arboretum, Harvard University. p. 265.
IPNI 2018. Available at http://www.ipni.org/. (accessed on 26.07.2018).

JARVIS C. 2007. Order out of Chaos: Linnaean Plant Names and their types. Linnean society of London. p. 339.

KUPCHAN S.M., DOSKOTCH R.W., BOLLINGER P., MCPHAIL A.T., SIM G.A. \& J.A. RENAULD 1965. The isolation and structural elucidation of a novel steroidal tumour inhibitor from Acnistus arborescens. Journal of American Chemical Society 87(24): 5805-5806.

KUPCHAN S.M., ANDERSON W.K., BOLLINGER P., DOSKOTCH R.W., SMITH R.M., RENAULD J.A.S., SCHNOES H.K., BURLINGAME A.L. \& D.H. SMITH 1969. Tumor inhibitors. XXXIX. Active principles of Acnistus arborescens. Isolation and structural and spectral studies of withaferin $A$ and withacnistin. The Journal of Organic Chemistry 34(12): 3858-3866.

LINNAEUS C. 1756. Centuria II Plantarum. Volume 2. L. M. Hojer, Upsala. p.10.

MABBERLEY J.D. 2017. Mabberley's plant - book. A portable dictionary of plants, their classification and uses Fourth edition. Cambridge University Press, Cambridge. p. 466.

NAIDU V.S.G.R. 2012. Handbook on weed identification. Directorate of Weed Science Research, Jabalpur, India. p. 354.

NARASIMHAN D., ARISDASON W., IRWIN S.J. \& G. GNANASEKARAN 2009. Invasive alien plant species of Tamil Nadu. In: Proceedings of the seminar on 'Invasive Alien species' held at Department of Environment, Govt. of Tamil Nadu. pp. 29-38.

PLUMIER C. 1703. Nova Plantarum Americanarum Genera. Joannem Boudot, Parisiis.

RAO A.N. \& B.S. CHAUHAN 2015. Weeds and weed Management in India-A review. Weed science in the Asian - Pacific Region. Indian Society of Weed Science, Jabalpur. pp. 87-118.

REDDY C.S, BAGYANARAYANA G., REDDY K.N. \& V.S. RAJU 2008. Invasive Alien Flora of India. National Biological Information Infrastructure, US Geological Survey, USA.

REEMA KUMARI M. 2004. A taxonomic revision of the Indian Solanceae. Ph D Thesis, Bharathiar University (Unpublished). pp. 27-28.

ROXBURGH W. 1795. Plants of the Coast of Coromandel. W. Bulmer \& Co., London.

SHARMA B.D., KARTHIKEYAN S. \& N.P. SINGH 2000. Flora of Maharashtra State. Volume 2. Botanical Survey of India, Kolkata., pp. 493-520. 
SHAW J. 2018. Response from Julian Shaw, Senior Registrar, RHS Botany Department. The Plantsman 17: 200.

STAFLEU A.F. \& R.S. COWAN 1983. Taxonomic literature. A selective guide to botanical publications and collections with dates, commentaries and types. Volume 4: P - Sak. Dr. W. Junk b.v. Publishers, The Hague/Boston. p. 301.

TURLAND N.J., WIERSEMA J.H., BARRIE
F.R., GREUTER W., HAWKSWORTH D.L., HERENDEEN P.S., KNAPP S., KUSBER W.-H., LI D.-Z., MARHOLD K., MAY T.W., MCNEILL J., MONRO A.M., PRADO J., PRICE M.J. \& G.F. SMITH (Eds.) 2018. International Code of Nomenclature for algae, fungi and plants (Shenzhen Code). [Regnum Vegetabile 159] Koeltz Botanical Books, Glashutten. 